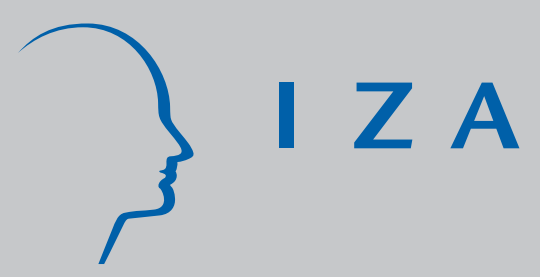

IZA DP No. 4131

Where the Girls Are:

Trade and Labor Market Segregation in Colombia

J osh Ederington

J enny Minier

Kenneth R. Troske

April 2009 


\title{
Where the Girls Are: Trade and Labor Market Segregation in Colombia
}

\author{
Josh Ederington \\ University of Kentucky \\ Jenny Minier \\ University of Kentucky \\ Kenneth R. Troske \\ University of Kentucky \\ and IZA
}
Discussion Paper No. 4131
April 2009

\author{
IZA \\ P.O. Box 7240 \\ 53072 Bonn \\ Germany \\ Phone: +49-228-3894-0 \\ Fax: +49-228-3894-180 \\ E-mail: iza@iza.org
}

\begin{abstract}
Any opinions expressed here are those of the author(s) and not those of IZA. Research published in this series may include views on policy, but the institute itself takes no institutional policy positions.

The Institute for the Study of Labor (IZA) in Bonn is a local and virtual international research center and a place of communication between science, politics and business. IZA is an independent nonprofit organization supported by Deutsche Post Foundation. The center is associated with the University of Bonn and offers a stimulating research environment through its international network, workshops and conferences, data service, project support, research visits and doctoral program. IZA engages in (i) original and internationally competitive research in all fields of labor economics, (ii) development of policy concepts, and (iii) dissemination of research results and concepts to the interested public.
\end{abstract}

IZA Discussion Papers often represent preliminary work and are circulated to encourage discussion. Citation of such a paper should account for its provisional character. A revised version may be available directly from the author. 
IZA Discussion Paper No. 4131

April 2009

\section{ABSTRACT \\ Where the Girls Are: Trade and Labor Market Segregation in Colombia*}

Gary Becker's theory of discrimination argues that increasing competition will reduce discrimination in the labor market. We use the Colombian trade liberalization episode over the period 1984-91 to investigate this claim on plant-level data in three ways. First, we examine whether women are concentrated in exporting plants. Second, we examine whether the increase in foreign competition due to unilateral trade liberalization disproportionately drove discriminating plants out of the market. Finally, we investigate whether trade liberalization affected hiring decisions (and thus gender segregation) by Colombian firms.

JEL Classification: J7

Keywords: discrimination, trade, competition

Corresponding author:

Kenneth R. Troske

Department of Economics

335 Gatton Business and Economics Bldg.

University of Kentucky

Lexington, KY 40506-0034

USA

E-mail: ktroske@uky.edu

*We'd like to thank Chris Bollinger, Chad Bown, and Mark Roberts for helpful discussions.

Any errors are, of course, our own. 


\section{Introduction}

One of the main predictions of Gary Becker's canonical model of discrimination (1957) is that, as long as there are some potential employers with no taste for discrimination, competitive forces will drive discriminating employers from the market in the long run. Despite the fact that this is one of the strongest predictions of the Becker model, there have been relatively few attempts to test this prediction. The few papers that have examined this hypothesis have produced conflicting findings, been limited to a specific sector, or used measures that are imperfect proxies for competition. For example, Hellerstein, Neumark, and Troske (2002) find evidence that women are paid wages that are less than their marginal product in sectors with a high degree of firm concentration (that is, only in sectors where firms have some market power). However, they find no evidence that these potentially discriminating firms are more likely to exit the market. Black and Strahan (2001) examine deregulation in the banking industry and find that, after deregulation, women's relative wages increased, as did their share in managerial positions. Finally, Black and Brainerd (2004) find that increases in the import penetration ratio in a manufacturing industry - their measure of competition — led to a fall in the gender wage gap in the industry.

This paper makes three main contributions to the literature on competition and gender discrimination. First, one interpretation of Becker's prediction is that since exporting firms face more competition than firms that produce only for the domestic market, exporters should discriminate less than non-exporters. Previous studies of employment in developing countries have typically found that women are concentrated in the exportoriented industries of the manufacturing sector such as textiles and food products (e.g., Catagay and Berik (1991) and Ozler (2000)). However, it is difficult to determine if this female concentration is due to the exporting nature of those industries, or to some unobserved industry characteristics. In this paper we investigate whether women are more likely to be employed in exporting firms within an industry. Using Colombian manufacturing data we find that this is the case: the female share of employment is higher among exporting firms, and is increasing in the amount of exporting done by a firm.

Second, previous research on the effects of foreign competition on gender discrimination has relied, almost exclusively, on household- or individual-level data, and has used import penetration measures in a sector (i.e., the ratio of imports to domestic shipments) to proxy for the degree of foreign competition, where increases in import penetration are interpreted as reflecting increases in competitive pressures (e.g., see Berik, Rodgers, and Zveglich (2004), Black and Brainerd (2004), Hazarika and Otero (2004) and Menon and van der Meulen Rodgers (2009)). ${ }^{1}$ These previous studies have several limitations. First, since workers cannot be directly linked to firms, the effect of changes in competitive pressures on the extent of labor market discrimination can only be inferred by examining

\footnotetext{
${ }^{1}$ Exceptions to this are the Black and Strahan (2001) paper, which uses regulatory changes in the banking industry as a proxy for changes in the amount of competition in a sector, and the Hellerstein et al. (2002) paper, which uses plant-level data.
} 
changes in the relative wages of workers in a sector. The primary implication of the Becker model concerns the effect of competition on firm hiring decisions: increases in competition in a sector lead to the growth of less discriminatory firms which proportionally hire more women. The impact on relative wages occurs indirectly through the relative growth in demand for female workers, and need not occur at all if there are a sufficient number of nondiscriminatory employers. Therefore, studies using worker-level data cannot directly examine the main implications of the Becker model.

Another limitation of these previous studies is that the change in the import penetration ratio in a sector is an imperfect proxy for the degree of competition in that sector. In particular, in the absence of a change in trade flows, a decrease in domestic competition (resulting in a decrease in domestic production of the industry) would also result in an increase in import penetration. As a result, changes in import penetration do not necessarily reflect changes in competitive pressure.

In contrast to previous studies, we use plant-level data to directly examine the impact of changes in the degree of competition on firm hiring decisions and we exploit a natural experiment: the Colombian trade liberalization episode of 1984. Starting in 1985, and following its entry into the GATT/WTO, Colombia undertook major unilateral trade liberalization of its manufacturing sector. This liberalization entailed both a reduction in the average level of protection, but also a collapsing of the distribution of protection as Colombia moved to a more uniform tariff structure. In this paper, we exploit this crosssectional variation in tariff reductions to see if a greater increase in foreign competition (i.e., a larger tariff reduction) resulted in less gender discrimination across Colombian firms. Both of these differences enable us to more directly examine the implications of the Becker model.

Finally, the Becker model of competition and discrimination is commonly interpreted as one where competition forces discriminating firms from the market. Firms that have a "taste for discrimination" (i.e., place a negative valuation on hiring women) tend to have higher costs and thus lower profits than their less discriminating counterparts. To the extent that capital investment will only flow to the more profitable (non-discriminating) firms, competition will force the discriminating firms from the market in the long run. Thus, the Becker model is commonly interpreted as one where competition reduces discrimination in the long run through selection effects (i.e., by forcing discriminating firms to exit the market). However, as we show in a brief theoretical section, competition can also reduce discrimination in the short run by increasing the marginal cost of discriminating behavior. That is, firms that perceive a tradeoff between profits and the female share of their workforce would respond to increased competition by hiring more women. Another advantage of the Colombian data is that it is plant-level, which allows us to differentiate between these two forces and measure the extent to which increased foreign competition induces discriminating plants (i.e., plants with low female shares) to exit relative to the extent to which it induces all plants to increase the female share of their labor force.

The primary conclusion of this paper is that increased competition reduces discrimi- 
nation by affecting the hiring practices of firms. That is, we find that firms in industries that saw the greatest reduction in tariffs increased the female share of their work force more than firms in industries that saw little or no reduction in tariffs. In contrast, we find little evidence that trade liberalization drove discriminating firms out of the market.

\section{Gender Discrimination: Theory}

In this section we present a model of competition and gender discrimination. We follow Becker (1957) and Arrow (1973) in assuming that firms are not strictly profit-maximizers but rather maximize a utility function that evidences a tradeoff between profits and the number of male and female employees. However, in contrast to Becker (1957) and Arrow (1973), we explicitly assume a monopolistically competitive environment that allows both discriminating and non-discriminating firms to coexist in equilibrium. The question of interest is the effect of an increase in competition on the equilibrium.

We assume an economy with two sectors: one sector consists of a numeraire good, $x_{0}$, while the other sector is characterized by differentiated products. The preferences of a representative consumer are defined by the following utility function:

$$
U=x_{0}+\log \left[\int_{0}^{n} y(j)^{\rho} d j\right]^{1 / \rho}
$$

where $x_{0}$ is consumption of the numeraire good, $y(j)$ represents consumption of brand $j$ of the differentiated product good and $n$ represents the number of available varieties (firms) in the differentiated product sector. Note that we adopt a CES specification, which reflects tastes for variety in consumption and also imposes a constant (and equal) elasticity of substitution between every pair of goods. Indeed, it is straightforward to show that with these preferences, the elasticity of substitution between any two products is $\sigma=1 /(1-\rho)>1$, and aggregate demand for brand $i$ is given by:

$$
y(i)=\frac{p(i)^{-\sigma} E}{\int_{0}^{n} p(j)^{1-\sigma} d j}
$$

where $p(i)$ is the price of good $i$ and $E$ represents the total number of consumers in the country.

We assume that production of the differentiated product good requires a sequence of tasks to be performed (for example, in the automobile sector, one task might involve installing the brakes and another task might be installing the windshield). This treatment of production is similar to that of Becker and Murphy (1992) and Kremer (1993). Rather than assuming a discrete set of tasks, it will be convenient to assume production is defined by the completion of a continuum of tasks along the unit interval. Letting $t$ be the index for tasks and letting the cost of task $t$ be given by $w(t)$, then the marginal cost of producing a variety of the differentiated product good is given by: 


$$
c=\int_{0}^{1} w(t) d t
$$

We assume that either a male employee can be hired to complete a task at cost $w_{m}$ or a female employee can be hired at cost $w_{f}$ where $w_{m}>w_{f}$ (thus, we assume that male and female employees are equally productive in producing the differentiated product, but that there exists a wage differential in the economy). ${ }^{2}$ Defining $z_{i} \in[0,1]$ as the fraction of females employed by firm $i$, the marginal costs of firm $i$ are given by:

$$
c_{i}=w_{m}-z_{i}\left(w_{m}-w_{f}\right)
$$

It should be clear that, given the existence of a wage differential, a cost-minimizing firm will choose to hire only women (i.e., set $z_{i}=1$ ). However, as discussed previously, we assume firms maximize a utility function that encompasses both profits and a "taste for discrimination," which we capture by assuming that the firm owner/manager derives extra disutility from hiring female workers, defined by $\phi_{i}\left(z_{i}\right)$. Note that we assume the Arrow version of Becker's model, in which firms care only about the fraction of their workforce that is female (i.e., firms care about $z_{i}$ ). Thus, firms choose price, $p_{i}$, and the female share of the labor-force, $z_{i}$, to maximize:

$$
\max _{p_{i}, z_{i}}\left(p_{i}-c_{i}\right) y_{i}-\phi_{i}\left(z_{i}\right)
$$

where $\phi_{i}^{\prime}\left(z_{i}\right)>0$ and $\phi_{i}^{\prime \prime}\left(z_{i}\right)<0$. From the first-order condition with respect to $p_{i}$, one can derive that firms use a constant mark-up pricing rule where:

$$
p_{i}=\frac{\sigma}{\sigma-1} c_{i}
$$

From the first-order condition with respect to $z_{i}$, one can derive that $z_{i}$ is implicitly defined by:

$$
\phi_{i}^{\prime}\left(z_{i}\right)=\frac{\sigma-1}{\sigma} \frac{\left(w_{m}-w_{f}\right) E\left[w_{m}-\left(w_{m}-w_{f}\right) z_{i}\right]^{-\sigma}}{\int_{0}^{n}\left(c_{j}\right)^{1-\sigma} d j}
$$

The left hand side of (7) represents the marginal cost to the firm of increasing the female share of its employees while the right hand side represents the marginal benefit (in lower costs of production). Firms will choose to employ men (i.e., $z_{i}<1$ ) if and only if the marginal disutility of hiring women is sufficiently high (and outweighs the cost of the wage differential). ${ }^{3}$

\footnotetext{
${ }^{2}$ This wage differential is simply taken as exogenous in the differentiated product sector. It can be generated either by discrimination or productivity differences in the numeraire product sector. For example, assuming each male employee can produce $w_{m}$ units of the numeraire good and each female employee can produce $w_{f}$ units of the numeraire good, production of the numeraire good in positive amounts would fix wages in the economy at $w_{m}$ and $w_{f}$ respectively.

${ }^{3}$ There also exists a second-order condition on $\phi_{i}^{\prime \prime}\left(z_{i}\right)$, which we assume is satisfied, that ensures an interior solution.
} 
There are two items to note about the above derivations. First, firms with the greatest "taste for discrimation" (i.e., with the highest values of $\phi_{i}^{\prime}\left(z_{i}\right)$ for any $\left.z_{i}\right)$ will employ the lowest share of female workers (i.e., choose the lowest $z_{i}$ ). As in Becker (1957) and Arrow (1973), the female share of the workforce will vary across firms, with more discriminating firms employing a lower share of women and less discriminating firms employing a higher share. In addition, the more discriminating firms, since they have higher marginal costs of production (i.e., higher $c_{i}$ ), will be less profitable than the less discriminating firms. As Becker (1957) and Arrow (1973) note, one would expect that, in a competitive environment, capital would flow to the more profitable (less discriminating firms) and in the long run the more discriminating firms would be pushed out of the market. Thus, the traditional theory of discrimination argues that competition reduces discrimination in the long run through a selection effect where only the most profitable (least discriminating) firms survive.

However, these derivations suggest a second mechanism through which competition can affect discrimination: by affecting firms' hiring decisions (i.e., by affecting the optimal choice of $z_{i}$ ). For expositional simplicity, assume that firms are symmetric and have identical utility functions (i.e., $z_{i}=z$ in equilibrium). In this case, the first-order condition (7) reduces to:

$$
\phi_{i}^{\prime}\left(z_{i}\right)=\frac{\sigma-1}{\sigma} \frac{\left(w_{m}-w_{f}\right) E}{\left[w_{m}-\left(w_{m}-w_{f}\right) z\right] n}
$$

Now assume there is an exogenous increase in competition captured by an increase in the elasticity of substitution, $\sigma$ (note that as $\sigma \rightarrow \infty$, the CES preferences take the linear form: the goods become perfect substitutes and the market mimics perfect competition). Taking a derivative of the right hand side of (8) with respect to $\sigma$ one derives that:

$$
\frac{\partial R H S}{\partial \sigma}=\frac{1}{\sigma^{2}} \frac{\left(w_{m}-w_{f}\right) E}{\left[w_{m}-\left(w_{m}-w_{f}\right) z\right] n}>0
$$

An increase in competition will increase the marginal benefit of employing more women, increasing the female share of a firm's workforce (i.e., increasing $z_{i}$ ). This negative impact of competition on discrimination is due to an elasticity effect: firms that face a more elastic demand for their product will incur a higher cost to discriminating behavior, as the resulting increase in costs and prices causes a correspondingly greater loss of market share. To the extent that greater competition increases the elasticity of demand for a firm's product, such competition will increase the cost of discriminating behavior resulting in the hiring of more female employees. Indeed, Krugman (1979) provides a model of monopolistic competition and international trade in which one of the pro-competitive aspects of trade is that it increases the elasticity of demand faced by firms.

However, one could also think of an increase in competition as an exogenous increase in the number of firms in the market (perhaps due to a decline in entry costs). Taking a derivative of the right hand side of (8) with respect to $n$ (and holding $\sigma$ constant) yields: 


$$
\frac{\partial R H S}{\partial n}=\frac{1-\sigma}{\sigma n^{2}} \frac{\left(w_{m}-w_{f}\right) E}{\left[w_{m}-\left(w_{m}-w_{f}\right) z\right]}<0
$$

In this case, an increase in competition (modeled as an exogenous increase in the number of firms), will decrease the marginal benefit of hiring women and so will decrease the share of female employees (increase gender discrimination). This positive effect of competition on discrimination is due to a scale effect: larger firms suffer a greater cost to discriminating behavior since the increased marginal costs of production that result from such behavior affect a larger volume of production. To the extent that greater competition reduces firm size, it might reduce the costs of discrimination and result in the hiring of more male employees.

To summarize, the overall effect of competition on discrimination reflects a combination of elasticity and scale effects. Note that the force of these effects depends partially on the degree of existing competition in the market. For example, it is direct to derive from the above calculation that the elasticity effect is decreasing in $\sigma$ (see equation (9)) and the scale effect is increasing in $\sigma$ (see equation (10)). Thus, in industries that are already sufficiently non-competitive (i.e., have a sufficiently small $\sigma$ ), the elasticity effect will tend to dominate, and competition should reduce the degree of gender discrimination. This might not be the case in industries that are sufficiently competitive (i.e., have a sufficiently large $\sigma$ ), where the scale effect will tend to dominate. In other words, the impact of competition on hiring decisions and the degree of gender discrimination could be a function of the existing degree of competition in the industry. ${ }^{4}$ Some empirical evidence for this conditional result can be found in Black and Brainerd (2004), in which the impact of trade volume on gender wage differentials depends on the degree of concentration of the industry.

\section{Data: Colombian Trade Liberalization}

In this paper we use plant-level panel data from Colombia to examine the prediction of the Becker model that changes in the level of competition reduces discrimination in the labor market. Like many developing countries, Colombia followed a policy of import substitution in the 1950s and 1960s. In the 1970s, this policy was reconsidered as Colombia sought entry into the GATT. Starting in 1985 and culminating in 1991, Colombia systematically lowered its trade barriers with the aim of creating a relatively uniform structure of protection comparable to those in developed countries. Since high tariffs shield domestic producers from competitive pressures from producers in other countries, we treat changes in tariffs as changes in the level of competition faced by firms in Colombia.

\footnotetext{
${ }^{4}$ Both the scale and elasticity effects are decreasing as one increases the number of firms, $n$, in the market.
} 


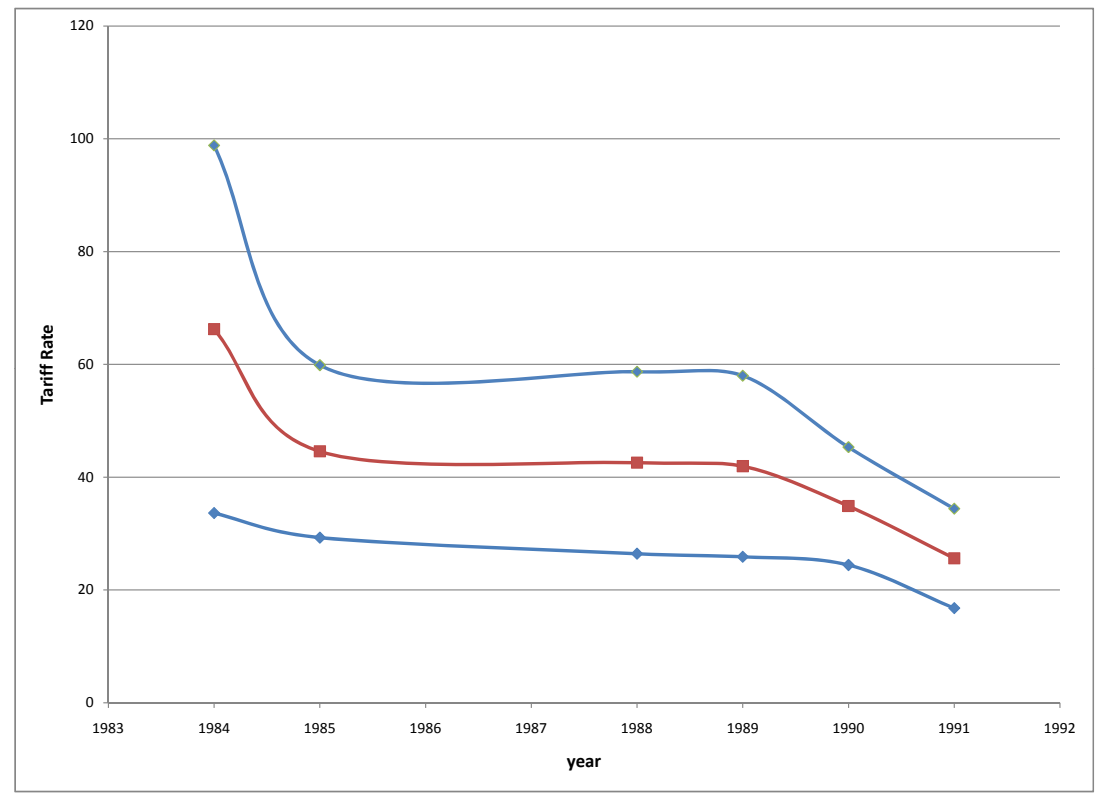

Figure 1: Mean Tariff by Year

This episode of trade liberalization has been extensively studied in the international trade literature since several of its features make it attractive from an empirical standpoint. ${ }^{5}$ First, prior to liberalization, Colombia had relied primarily on tariffs as a means of trade protection and so the decline in tariffs was significant (the average tariff reduction was 31.4 percentage points between 1984 and 1991), and also provides an accurate measure of the overall change in trade policy. ${ }^{6}$ Second, the Colombian trade liberalization had a significant impact on the structure of protection, with some industries receiving extensive tariff cuts while other industries were not significantly affected. It is this variation in tariff reductions that we exploit in our empirics. Finally, the main policy objective of the Colombian government was to achieve uniformity in tariff levels across industries, and to make their tariff levels comparable to those of other WTO members as part of Colombia's entry into the GATT/WTO. ${ }^{7}$ Thus, the Colombian tariff reductions were

\footnotetext{
${ }^{5}$ A partial list of international papers that have studied Colombia includes Roberts and Tybout (1997), Fernandes (2007), Goldberg and Pavcnik (2005), Brooks (2006) and Goldberg and Pavcnik (2007).

${ }^{6}$ Unfortunately, while non-tariff barriers were also reduced as part of the reform, complete data on the reductions in such barriers is not available. However, as mentioned, tariffs were the primary policy instrument and the available data suggests that tariff levels (and changes) are positively correlated with NTB levels (and changes) across industries in our dataset. See Goldberg and Pavcnik (2005) for more details.

${ }^{7}$ Colombia entered the GATT in 1981, but used developing-country exemptions to avoid tariff reduc-
} 


\section{Table 1: Summary Statistics}

\begin{tabular}{lrrr}
\hline & \multicolumn{1}{c}{ Mean (s.d.) } & \multicolumn{1}{c}{ Mean (s.d.) } & \multicolumn{1}{c}{ Change } \\
Variable & $0.365(0.286)$ & $0.355(0.265)$ & $0.007(0.145)$ \\
\hline Female share, total & $0.341(0.354)$ & $0.314(0.333)$ & $-0.005(0.164)$ \\
Female share, unskilled & $0.497(0.301)$ & $0.504(0.269)$ & $0.024(0.261)$ \\
Female share, skilled & & & \\
& $0.018(0.101)$ & $0.042(0.151)$ & \\
Exports & $14.55(12.23)$ & & \\
Firm age & $3.55(1.02)$ & $3.34(1.15)$ & \\
Employment (log) & $5.25(0.43)$ & $6.83(0.46)$ & \\
Salary (log) & $0.213(0.168)$ & $0.269(0.213)$ & \\
Skill ratio & $2.67(1.15)$ & $4.65(1.30)$ & \\
Energy use (log) & $6.31(0.80)$ & $8.19(0.93)$ & \\
Productivity (log) & $4.94(1.41)$ & $6.58(1.58)$ & \\
Capital/labor $(\log )$ & $0.083(0.111)$ & $0.094(0.128)$ & \\
Office equipment & $0.202(0.283)$ & $0.237(0.295)$ & \\
Female management & & & \\
& $0.170(0.376)$ & $0.174(0.379)$ & \\
Corporation & $0.139(0.346)$ & $0.123(0.329)$ & \\
Proprietorship & $0.691(0.462)$ & $0.703(0.457)$ & \\
Partnership & & & \\
& $0.662(0.328)$ & $0.257(0.088)$ & \\
Tariff & & & \\
& $0.400(0.192)$ & & \\
4-firm concentration & 6,035 & 6,972 & \\
\hline Obsservations &
\end{tabular}

Notes to Table: See Appendix A for variable definitions. Changes are the average of the changes for plants for which we have data in both 1984 and 1991.

less susceptible to industry pressure or governmental preferences, and can be plausibly treated as exogenous. Evidence on both the decline in overall tariffs and the narrowing of tariff differences across sectors is provided in Figure 1, which shows the mean tariff by year across the plants in our sample. Note both the significant average decline, and the narrowing of the dispersion of tariffs.

All data come from a plant-level dataset produced from the Colombian Manufacturing census by DANE (National Statistical Institute) for the years 1977 through 1991. ${ }^{8}$ This

tions until the trade liberalization episode studied in this paper. For an overview of the evolution of trade policy in Colombia see Goldberg and Pavcnik (2005) and Fernandes (2007).

${ }^{8}$ We would like to thank Mark Roberts for making the Colombian manufacturing census data available to us. For a complete description of all the variables used in our estimation, see the Appendix A, and see Roberts (1996) for a description of this dataset. 
is an unbalanced panel covering industrial production in all 3-digit ISIC industries in Colombia. For each year the survey collects data on production, sales, inputs, inventories, exports and the industry code (4-digit ISIC) of each Colombian plant. It should be noted that plants with less than 10 employees are included in the census prior to 1982 , but excluded after 1983 (although a small proportion are included following 1985). Our sample includes a total of 6,035 plants in 1984; 3,760 remain in the sample in 1991, which totals 6,972 plants. ${ }^{9}$ The Colombian manufacturing industry is characterized by relatively small-scale plants ( $70 \%$ of production is by plants employing fewer than 50 workers), and high levels of entry and exit (with average entry rates of $11 \%$ and exit rates of $10 \%$ ). ${ }^{10}$ However, the distribution of plants across industries is relatively constant over time with the major industries being food, apparel, textiles, printing and metal products. For measures of trade liberalization, we employ ad-valorem tariff levels and effective rates of protection that are available at the 4-digit ISIC level from the Departamento Nacional de Planeación. ${ }^{11}$

Table 1 presents summary statistics for our data. Most of our analysis concentrates on the change between 1984 and 1991, so Table 1 includes means for both years where applicable, as well as the mean change in the relevant variables. Some trends stand out: between 1984 and 1991, average tariffs dropped dramatically; exports (as a share of production) increased; and plants became more productive, used more energy, and paid higher wages. ${ }^{12}$ There was virtually no change, however, in the average female share of total workers over this period, although the female share of skilled workers increased slightly.

Since we are examining the female share of workers in Colombian plants, it is worth briefly discussing female labor force participation in Columbia more generally. Colombia's female labor force participation was higher than that of most Latin American countries: in the early 1990s, it was 43\%, approximately ten percentage points higher than the Latin American average. This is generally attributed to more widely available contraception in Colombia (between 1964 and 1994, fertility rates fell from 7.4 to 2.7 children per woman) and very high violent crime rates for men, leading to a high probability of widowhood. ${ }^{13}$ In addition, between 1984 and 1991 female labor force participation rates rose fairly dramatically, particularly for younger women (see Arango and Posada (2005a, 2005b)). Female workers are, not surprisingly, concentrated in the apparel and textile industries; in 1984, the female share of workers in these (4-digit) industries was as high as $80 \%$, relative to the overall average of $35 \%$.

\footnotetext{
${ }^{9}$ In some of the analysis that follows, sample sizes are reduced due to missing data. In addition, we drop approximately $2 \%$ of the sample classified as "other" types of enterprise (cooperatives, collectives, etc.) in the analyses that follow.

${ }^{10}$ See Fernandes (2007).

${ }^{11}$ We would like to thank Jorge Garcia-Gracia at the World Bank for making these data available.

${ }^{12}$ All wages are measured in nominal dollars, so it is not surprising that wages rose over this period.

13 "Women in Colombia Move to Job Forefront," The New York Times, July 15, 1994.
} 


\section{Exports and the Female Labor Share of Colombian Plants}

As mentioned in the Introduction, one interpretation of exporting firms is that they face higher degrees of competition than non-exporting firms, because they compete in international markets. As a result, one might expect exporters to discriminate less than non-exporters. Studies of employment in developing countries have typically found that women are concentrated in the export-oriented industries of the manufacturing sector (e.g., Catagay and Berik (1991) and Ozler (2000)), which typically includes the textile, garment, electronics, leather and agricultural processing industries. However, it is difficult to determine if this female concentration is due to the exporting nature of those industries, or simply to unobserved industry characteristics. Indeed, Catagay and Berik (1991) and Ozler (2000) also find that women in developing countries are typically employed in low-paying, low capital-intensity, small-scale firms, hardly the standard characteristics of exporting firms (see Roberts and Tybout (1997) for empirical evidence on the types of firms that export). In this section, we investigate whether, in a given industry, women are more likely to be employed by exporting firms.

Table 2 provides the results of a set of regressions where we regress the plant's female share of labor on a variety of plant-level characteristics (as well as 4-digit ISIC industry fixed effects to control for industry-level characteristics and year dummies to control for year effects). The dependent variable in column 1 of table 2 is the female share of total employment in the plant. As explanatory variables, we include the age of the plant, total employment in the plant (to proxy for size), and productivity of the plant (value added per employee). For this analysis, we use the full panel of firms from 1984 to $1991 .^{14}$ Given that existing literature suggests that women are concentrated in low-paying jobs, we include a measure of average wages of workers in the plant (the log of the total salary and wages of all workers in the plant divided by total employment in the plant). As additional explanatory variables, we include the energy share, capital share, skilled-labor share (skilled workers out of total employment) and office equipment share of the plant (as a measure of new technology used in the plant). Finally, the variable of interest is the export intensity of the plant (plant exports as percentage of total sales). ${ }^{15}$

As can be seen from Table 2, plants that employ more women tend to pay lower wages than the industry average. This result is consistent with our theoretical model, as well as standard models of discrimination in Becker (1957) and Arrow (1973), where the benefit of hiring female workers is exactly that you can pay them lower wages. These results are also consistent with work examining inter-firm segregation in the U.S. (i.e., Carrington and Troske (1998) and Hellerstein et al. (2002)). However, also note that establishments employing more women tend to be less capital- and energy-intensive, while establishments that employ more women tend to have larger stocks of office equipment (as a share of

\footnotetext{
${ }^{14}$ We do not include plant-level fixed effects, since our interest is in the within-industry variation in female share as a function of exports.

${ }^{15}$ Results are comparable with a dummy variable indicating exporting firms.
} 
Table 2: OLS: Which FiRMs ARE MORE FEMALE?

\begin{tabular}{lccc}
\hline & $(1)$ & $(2)$ & $(3)$ \\
& Total & Unskilled & Skilled \\
Variable & $\hat{\beta}($ s.e. $)$ & $\hat{\beta}($ s.e. $)$ & $\hat{\beta}$ (s.e. $)$ \\
\hline Exports & $0.090(0.014)^{* * *}$ & $0.109(0.019)^{* * *}$ & $-0.032(0.016)^{* *}$ \\
Firm age & $-0.0003(0.000)^{*}$ & $-0.001(0.0002)^{* * *}$ & $0.0003(0.000)$ \\
Employment $(\log )$ & $0.012(0.002)^{* * *}$ & $0.031(0.003)^{* * *}$ & $-0.071(0.003)^{* * *}$ \\
Salary $(\log )$ & $-0.044(0.005)^{* * *}$ & $-0.018(0.006)^{* * *}$ & $-0.072(0.008)^{* * *}$ \\
Skill ratio & $0.053(0.009)^{* * *}$ & $-0.121(0.014)^{* * *}$ & $-0.300(0.015)^{* * *}$ \\
Energy use $(\log )$ & $-0.013(0.002)^{* * *}$ & $-0.019(0.002)^{* * *}$ & $-0.010(0.003)^{* * *}$ \\
Capital/labor $(\log )$ & $-0.007(0.001)^{* * *}$ & $-0.007(0.002)^{* * *}$ & $-0.001(0.002)$ \\
Productivity $(\log )$ & $-0.005(0.002)^{* *}$ & $-0.006(0.003)^{* *}$ & $0.015(0.003)^{* * *}$ \\
Office equip & $0.018(0.014)$ & $0.019(0.019)$ & $0.075(0.021)^{* * *}$ \\
Female mgnt & - & $0.064(0.007)^{* * *}$ & $0.014(0.009)^{*}$ \\
Corporation & $-0.021(0.005)^{* * *}$ & $-0.025(0.007)^{* * *}$ & $0.010(0.006)$ \\
Proprietorship & $-0.018(0.005)^{* * *}$ & $-0.033(0.006)^{* * *}$ & $0.030(0.009)^{* * *}$ \\
\hline Observations & 53,497 & 52,228 & 49,065 \\
$\quad$ Plants & 10,933 & 10,798 & 10,144 \\
$\quad$ Industries & 96 & 96 & 95 \\
$R^{2}$ & 0.648 & 0.651 & 0.218 \\
\hline \hline
\end{tabular}

Notes to Table: The dependent variable is the plant's female share of workers; annual data are pooled 1984-91. Time and industry fixed effects are included, and standard errors are clustered by plant.

See Appendix A for data definitions and notes.

"Total" includes owners and managers, in addition to skilled and unskilled workers, in the calculation of the female share variable.

*** indicates statistical significance at the $99 \%$ level or better; ${ }^{* *}$ at $95 \%$; and ${ }^{*}$ at $90 \%$. 
total capital). Note that, as in Section 2, standard models of discrimination tend to assume that male and female workers are perfect substitutes but that discrimination results in female employees receiving a lower wage. The concentration of female workers in certain types of plants (e.g., non-capital-intensive) suggests that male and female employees might not be viewed as perfect substitutes, with female employees more likely to be assigned to certain tasks. This could be due to productivity differences across employees, leading women to have comparative advantage in certain jobs. Alternatively, it could be due to the "taste for discrimination" differing across jobs with plants being more willing to hire women to complete certain tasks.

The picture that emerges from Table 2 of plants that employ a greater percentage of women (less-capital/energy intensive, low-wage paying) is opposite the standard description of exporting firms in developing countries (e.g., see Roberts and Tybout (1997)). Despite this, Column 1 of Table 2 suggests that exporting plants employ a larger share of female employees. This result is at least consistent with the Becker hypothesis that firms that face greater competition (in this case competing for profits in foreign markets) are also less likely to discriminate against women.

Since women tend to be concentrated in clerical occupations, which are classified as skilled workers in these data, in regressions 2 and 3 of table 2, we present results when the dependent variable is the female share of unskilled and skilled labor, respectively. Note that regression 1 includes owners and managers, in addition to skilled and unskilled workers, so regression 1 is not simply an average of regressions 2 and 3 . In both regressions 2 and 3, we also add the female share of managers and owners, since women managers and owners may have less taste for discrimination of female workers; this seems to be the case, since in both regressions, the coefficient estimate on female management share is positive and statistically significant. The results for the unskilled labor share (regression 2) are quite similar to the overall sample: the coefficient estimate on exports is quantitatively very similar, and remains highly statistically significant. The main change is that the coefficient estimate on the skill ratio is negative and statistically significant, suggesting that plants with proportionally fewer skilled workers tend to have higher female shares of unskilled workers. Although this effect does not show up in regression 1 for the total female share, it fits with the finding that women are concentrated in firms that are less capital- and energy-intensive.

The results for the female share of skilled labor are also similar, with the notable exception that the coefficient estimate on exports is negative and statistically significant. This suggests that plants that export more - although they hire proportionally more women overall, and proportionally more female unskilled workers - tend to have lower female shares of skilled workers. One possible reason for this effect is that exporting plants tend to have multiple establishments with separate headquarters and production facilities, and clerical workers are located in the headquarters, rather than in the plants that appear in our data. 
Table 3: Industry Exit RATes 1984-91

\begin{tabular}{lc}
\hline & $(1)$ \\
Variable & $\hat{\beta}($ s.e. $)$ \\
\hline Exit rate 1977-81 & $0.076(0.108)$ \\
Tariff change 1984-91 & $-0.141(0.057)^{* * *}$ \\
constant & $0.259(0.038)^{* * *}$ \\
\hline Observations & 92 \\
$R^{2}$ & 0.074 \\
\hline \hline
\end{tabular}

Notes to Table: The dependent variable is the industry exit rate between 1984 and $1991 .^{* * *}$ indicates statistical significance at the $99 \%$ level or better; ${ }^{* *}$ at $95 \%$; and ${ }^{*}$ at $90 \%$. Mean probability of exit: 0.340 (0.163). 2 industries $(3842,3902)$ have all firms exit between 1984 and 1991.

\section{Competition and Plant Exit}

As mentioned previously, the argument made in Becker (1957) and Arrow (1973) was that competition should reduce discrimination by inducing the exit of discriminating firms (which would have higher costs and lower profits than non-discriminating firms). While this is primarily a long-run argument, our interest is whether we can observe this effect in the short run. That is, does an exogenous increase in the degree of foreign competition (as we observe with the Colombian trade liberalization episode) induce discriminating firms (i.e., firms with lower female shares) to exit the market? Indeed, the recent literature on firm heterogeneity and trade stresses the ability of trade to improve aggregate industry productivity through exactly such selection effects. Specifically, trade can induce productivity improvements by causing more productive firms to expand while less productive firms shrink or exit the market (e.g., see Melitz (2003)). The obvious parallel is the potential for trade competition to reduce discrimination by inducing discriminating (i.e., less efficient) firms to shrink or exit the market. ${ }^{16}$

In Table 3, we regress industry exit rates on the tariff change induced by the Colombian trade liberalization episode of 1984-91, as well as past exit rates to control for industry-specific effects. As can be seen, industries that experienced the most significant tariff reductions (largest negative tariff change) also saw higher exit rates, so the increase in foreign competition does appear to have induced exit by Colombian firms. The question of interest in this section is whether plants with low female shares are disproportionately represented among these exiting plants. To investigate this question, we run a logit regression predicting the probability of plant exit (between 1984 and 1991) with the plant's female share of its labor force as an explanatory variable. Results appear in Table 4.

\footnotetext{
${ }^{16}$ It should be noted that these models of trade competition and productivity typically work through the export side of the market. Thus, the parallel to the Colombian trade liberalization episode is not direct, as unilateral trade liberalization in Melitz (2003) has no impact on the productivity distribution of firms.
} 
Table 4: Logit: Probability of Firm Exit

\begin{tabular}{lcc}
\hline & $(1)$ & $(2)$ \\
Variable & $\hat{\beta}($ s.e. $)$ & $\hat{\beta}($ s.e. $)$ \\
\hline Female share & $0.324(0.143)^{* *}$ & $-0.234(0.347)$ \\
Tariff & & $-0.007(0.003)^{* *}$ \\
Tariff $\times$ female share & & $0.006(0.005)$ \\
Exports & $0.707(0.297)^{* *}$ \\
Years of existence & & $-0.002(0.003)$ \\
Total employment $(\log )$ & $-0.625(0.042)^{* * *}$ \\
Salary (log) & & $0.015(0.116)$ \\
Productivity $(\log )$ & & $-0.474(0.060)^{* * *}$ \\
Skill ratio & & $-0.123(0.206)$ \\
Energy use (log) & & $-0.049(0.035)$ \\
Capital-labor ratio $(\log )$ & & $0.026(0.028)$ \\
Office equipment & & $0.611(0.304)^{* *}$ \\
Corporation & & $0.488(0.103)^{* * *}$ \\
Proprietorship & & $-0.028(0.084)$ \\
\hline Observations & & 6,032 \\
$\quad$ Of which, exited & 2,281 & 2,273 \\
Log likelihood & -3921.2 & -3604.0 \\
\hline \hline
\end{tabular}

Notes to Table: The dependent variable is the probability that the plant exits between 1984 and 1991 (note: change in SIC not treated as exit).

All explanatory variables are measured in 1984. See Appendix A for data definitions.

3-digit industry dummy variables are also included in both regressions.

${ }^{* * *}$ indicates statistical significance at the $99 \%$ level or better; ${ }^{* *}$ at $95 \%$; and ${ }^{*}$ at $90 \%$. 
In regression 1 of Table 4, we regress the probability of exit on the female share of the labor force and include 3-digit SIC dummy variables. As can be seen, an establishment with a higher female share was, on average, more likely to exit the industry between 1984 and 1991. Recall that women also tend to be concentrated in less capital-intensive, low-wage plants so it is possible that women are overrepresented in exiting plants simply due to the fact that they are concentrated in the types of plants that would be most likely to exit. In regression 2 of Table 4 we include the vector of plant characteristics used in Section 4, adding tariffs and an interaction term between tariffs and the female share. As can be seen, controlling for other plant characteristics causes the coefficient estimate to become negative and no longer statistically significant. ${ }^{17}$ It remains the case that we fail to find evidence for the proposition that an exogenous increase in competition drives discriminating firms from the market, at least in the short run.

\section{Competition and Firm Hiring Decisions}

While the previous section fails to find evidence that increased competition due to trade liberalization forced discriminating plants from the market, a second possibility is that the increase in foreign competition influenced plant hiring decisions. In this section, we look for evidence that an exogenous increase in foreign competition induced plants to increase the female share of their workforce. To investigate this question, we use differences in the change in plants' female labor shares between 1984 and 1991. 1984 corresponds to the high point of average protection in Colombia, while 1991 is the final year of data available to us. We regress this change in the female share on the tariff change in the industry. ${ }^{18}$ Thus, we are exploiting cross-sectional variation in the degree of trade liberalization across industries to see if establishments in industries that experienced a greater decline in tariff protection responded by increasing the female share of their labor force. To control for plant-level characteristics that might influence hiring decisions, we include the female share of the plant in 1984. To control for industry-level characteristics, we include 3 -digit industry dummy variables. ${ }^{19}$ Results of this estimation are presented in Table 5 .

\footnotetext{
${ }^{17}$ Results are very similar for both subsamples when we estimate regression 2 on exporting and nonexporting plants separately.

${ }^{18}$ For this analysis, our sample consists of plants that are in operation both in 1984 and 1991 . One possibility is that the change in female share is related to plant exit which, if true, would lead to a bias in our estimated coefficients. To investigate this possibility, we estimated a standard two-stage selection model where the first stage regression estimates the probability of plant exit. Since the results from the two-stage model are largly identical to the results reported in Table 5, and since a standard Hausman test fails to reject the hypothesis of no selection, we have chosen to report the results from the single equation model. Results from the two-stage model are available from the authors on request.

${ }^{19}$ Note that the inclusion of the plant's 1984 female share also partially corrects for censoring, in that a firm with an already high female share (i.e., close to 1) cannot increase its female share further. Also note that we can only include 3-digit industry dummies since our tariff-change variable is at the 4-digit level.
} 
Table 5: Effect of Tariff Change on Firms' Female Share of Workers

\begin{tabular}{lccc}
\hline & $(1)$ & $\hat{\beta}$ & $(2)$ \\
Variable & $\hat{\beta}($ s.e. $)$ & $\hat{\beta}($ s.e. $)$ & $\hat{\beta}($ s.e. $)$ \\
\hline tariff change 1984-91 & $-0.17(0.02)^{* * *}$ & $-0.16(0.02)^{* * *}$ & $-0.27(0.04)^{* * *}$ \\
female share 1984 & $-0.33(0.01)^{* * *}$ & $-0.33(0.01)^{* * *}$ & $-0.33(0.01)^{* * *}$ \\
4-firm concentration & - & $0.06(0.02)^{* * *}$ & $0.14(0.02)^{* * *}$ \\
tariff cho*conc4 & - & - & $0.26(0.06)^{* * *}$ \\
corporation & $-0.02(0.01)^{* * *}$ & $-0.02(0.01)^{* * *}$ & $-0.02(0.01)^{* * *}$ \\
proprietorship & $0.01(0.01)^{*}$ & $0.01(0.01)^{*}$ & $0.01(0.01)$ \\
\hline Observations & 3,763 & 3,763 & 3,763 \\
$R^{2}$ & 0.196 & 0.199 & 0.203 \\
\hline \hline
\end{tabular}

Notes to Table: The dependent variable is the change in the plant's share of (total) female workers between 1984 and 1991. 3-digit industry dummy variables are also included. (Tariffs and concentration ratios are measured at the 4-digit industry level.) $R^{2}$ does not include the effects of the constant terms.

As can be seen from regression 1 of Table 5, an increase in foreign competition (as captured by a decline in tariff protection) is associated with plants increasing their share of female employees. Recall that over this period, industries experienced (on average) a significant decrease in tariffs. Indeed, from Table 1, the average industry experienced a tariff change of -0.403 , which corresponds to an increase in the female labor share of their workforce of 0.069 relative to an industry which received no change in tariff protection. ${ }^{20}$ As a point of comparison, the average female share in 1984 of firms in the dataset is 0.365 , so an increase of 0.069 corresponds to an 18.9 percent increase in female share. The Colombian trade liberalization episode appears to have had a significant impact on plants' hiring decisions and women's employment.

As discussed in the theoretical section, the effect of competition on hiring could also be a function of the existing degree of competition in the industry. To examine this hypothesis, in the third specification, we also include an interaction term between the 4 -firm concentration of the industry and the tariff change. Presumably, plants in more concentrated industries face less competition and should be more affected by any given change in tariffs. The sign on the interaction term suggests that the marginal effect of a tariff change on the female share is, somewhat surprisingly, lower in absolute value for firms in more concentrated industries. Specifically, at the 25th percentile of concentration (0.252) the marginal effect of a tariff change is -0.20 , while at the 75 th percentile $(0.531)$, it is only -0.13 .

In Table 6, we present regression results examining the impact that tariff changes have on the female shares of skilled and unskilled workers in a plant. These results largely mirror the results seen in Table 5, although tariff changes appear to have a larger impact

\footnotetext{
${ }^{20}$ Of 92 4-digit industries in the sample, five actually received increases in tariff protection over this period.
} 
Table 6: Effect of Tariff Change on Firms' Female Share By Skill Level

(1)

Unskilled Workers

\begin{tabular}{lcc} 
Variable & $\hat{\beta}($ s.e. $)$ & $\hat{\beta}($ s.e. $)$ \\
\hline tariff change 1984-91 & $-0.37(0.04)^{* * *}$ & $-0.22(0.06)^{* * *}$ \\
female share 1984 & $-0.29(0.01)^{* * *}$ & $-0.57(0.01)^{* * *}$ \\
4-firm concentration & $0.20(0.03)^{* * *}$ & $-0.01(0.04)$ \\
tariff chg*conc4 & $0.39(0.07)^{* * *}$ & $0.03(0.10)$ \\
corporation & $-0.02(0.01)^{* * *}$ & $-0.06(0.01)^{* * *}$ \\
proprietorship & $-0.00(0.01)$ & $0.06(0.01)^{* * *}$ \\
\hline Observations & 3,667 & 3,423 \\
$R^{2}$ & 0.185 & 0.337 \\
\hline Marginal effect & $-0.21(0.03)^{* * *}$ & $-0.21(0.04)^{* * *}$ \\
\hline \hline
\end{tabular}

(2)

Skilled Workers (1)

Notes to Table: The dependent variables are the change in the plant's share of female unskilled and skilled workers, respectively, between 1984 and 1991. 3-digit industry dummy variables are also included. "Female share 1984" is the share of unskilled and skilled labor, respectively. Concentration is at the 4-digit industry level.

"Marginal effect" is the marginal effect of a tariff change evaluated at the median level of concentration (0.387). $R^{2}$ does not include the effects of the constant terms.

on the female share of unskilled workers than on the female share of skilled workers. However, the marginal effect of a tariff change evaluated at the median concentration ratio $(0.39)$ is identical for the two groups, at -0.21 .

To further examine the hypothesis that the effect of tariffs could vary by the degree of competition in the industry prior to the tariff change, in Table 7 we estimate the regression from Table 6 separately by the exports status of plants in 1984. Since exporting plants already compete in international markets, it seems plausible that a decline in domestic tariffs would have a more significant impact on the competition facing non-exporting plants. Our results largely support this hypothesis. The last row of each panel includes the marginal effect evaluated at the mean of industry concentration. Looking at this row, we see that the effect of tariff change is larger among non-exporting plants, particularly in the case of skilled workers.

\section{Conclusion}

In this paper, we exploit plant-level data to show that Colombia's trade liberalization episode between 1984 and 1991 resulted in proportionally more women being hired by Colombian plants. This evidence is consistent with Becker's theory of discrimination, as well as with our slightly modified version of Becker's theory. We also find that this change occurs more because increasing competition leads existing plants to hire more women (as 
Table 7: EfFect of TARIfF Change By Export Status

(1) (2)

(3)

EXPORTING FIRMS ONLY

\begin{tabular}{lccc} 
& All Workers & Unskilled & Skilled \\
Variable & $\hat{\beta}($ s.e. $)$ & $\hat{\beta}$ (s.e. $)$ & $\hat{\beta}$ (s.e.) \\
\hline tariff change 1984-91 & $-0.36(0.08)^{* * *}$ & $-0.56(0.10)^{* * *}$ & $-0.07(0.11)$ \\
female share 1984 & $-0.26(0.03)^{* * *}$ & $-0.22(0.03)^{* * *}$ & $-0.52(0.04)^{* * *}$ \\
4-firm concentration & $0.23(0.05)^{* * *}$ & $0.35(0.06)^{* * *}$ & $-0.03(0.07)$ \\
tariff chg*conc4 & $0.42(0.11)^{* * *}$ & $0.63(0.14)^{* * *}$ & $0.01(0.16)$ \\
corporation & $-0.02(0.01)^{* *}$ & $-0.02(0.01)$ & $-0.03(0.02)^{* *}$ \\
proprietorship & $0.08(0.04)^{* *}$ & $0.06(0.04)$ & $0.13(0.05)^{* *}$ \\
\hline Observations & 519 & 518 & 511 \\
$R^{2}$ & 0.339 & 0.338 & 0.335 \\
Marginal effect & $-0.17(0.05)^{* * *}$ & $-0.28(0.07)^{* * *}$ & $-0.06(0.08)$ \\
\hline
\end{tabular}

Non-EXPORTING FiRms OnLY

\begin{tabular}{lccc} 
& All Workers & Unskilled & Skilled \\
Variable & $\hat{\beta}$ (s.e. $)$ & $\hat{\beta}$ (s.e. $)$ & $\hat{\beta}$ (s.e.) \\
\hline tariff change 1984-91 & $-0.26(0.04)^{* * *}$ & $-0.33(0.05)^{* * *}$ & $-0.20(0.07)^{* * *}$ \\
female share 1984 & $-0.35(0.01)^{* * *}$ & $-0.29(0.01)^{* * *}$ & $-0.58(0.02)^{* * *}$ \\
4-firm concentration & $0.14(0.03)^{* * *}$ & $0.19(0.03)^{* * *}$ & $-0.01(0.05)$ \\
tariff chg*conc4 & $0.23(0.07)^{* * *}$ & $0.35(0.08)^{* * *}$ & $-0.04(0.12)$ \\
corporation & $-0.02(0.01)^{* *}$ & $-0.02(0.01)^{* * *}$ & $-0.06(0.01)^{* * *}$ \\
proprietorship & $0.01(0.01)$ & $-0.00(0.01)$ & $0.06(0.01)^{* * *}$ \\
\hline Observations & 3,244 & 3,149 & 2,912 \\
$R^{2}$ & 0.205 & 0.182 & 0.345 \\
\hline Marginal effect & $-0.18(0.03)^{* * *}$ & $-0.20(0.03)^{* * *}$ & $-0.22(0.05)^{* * *}$ \\
\hline \hline
\end{tabular}

Notes to Table: The dependent variable is the change in the plant's share of (total) female workers between 1984 and 1991. 3-digit industry dummy variables are also included. (Concentration is at the 4-digit industry level.)

"Marginal effect" is the marginal effect of a tariff change evaluated at the median concentration ratio (0.43 for exporting firms; 0.37 for non-exporters). $R^{2}$ does not include the effects of the constant terms. 
the cost of discriminating increases), rather than forcing them out of the market. The effect of tariff liberalization on the female share of workers is quantitatively large: the average decrease in tariffs over this period corresponds to a 6.9 percentage point increase in the female share, relative to an industry with no change in tariffs. We are also able to elaborate on earlier research that found that women are concentrated in exporting industries, by showing that women are also concentrated in exporting plants. Finally, we show that the effect of tariff liberalization is larger for non-exporting plants than for plants that were exporting prior to liberalization - a finding that is consistent with the prediction of our model that the impact of increasing competition will be greater for firms that initially face little competitive pressure.

Importantly, our findings provide some evidence on how changes in competitive pressure lead to less labor market discrimination and help resolve a puzzle in the existing literature. In Becker's original model, competition leads to less discrimination by driving discriminating firms from the market. However, despite evidence that discrimination leads to lower wages and levels of employment for women and that discriminating firms earn higher profits (see Hellerstein, Neumark, and Troske (1999), Black and Strahan (2001), Hellerstein et al. (2002), and Black and Brainerd (2004)) there is little evidence that competition drives discriminating firms from the market (see Hellerstein et al. (2002)). In our modified version of the Becker model, we show that increases in competition can also reduce discrimination by raising the cost of discrimination, which pushes discriminating employers to hire more women. Our evidence is consistent with this being the primary mechanism through which competition leads to less discrimination. Thus, our results provide new evidence about the importance of enhancing competition as a way to reduce the extent of discrimination in the labor market. 


\section{A Data}

All data are taken from a plant-level dataset produced from the Colombian Manufacturing census by DANE (National Statistical Institute) for the years 1977 through 1991. From 1983 on, the census covers industrial production for plants with greater than 10 employees. Our empirics concentrate on plants which were operating in both 1984 and 1991. For a thorough description of this dataset see Roberts (1996).

\section{A.1 Variable Definitions and Notes}

All variables are measured at the plant level unless otherwise noted.

Female share: female share of workers (total, unskilled, and skilled as described in text). Productivity: value added for the plant divided by total employment.

Employment: total employment.

Firm Age: years since the plant's establishment until 1984.

Exports: plant exports scaled by total sales.

Salary: total payroll divided by total employment.

Skill Ratio: share of skilled employment in skilled and unskilled employment.

Capital/Labor Ratio: ratio of fixed capital to total employment. A small number of plants with fixed capital reported as zero are dropped. (In Table 4, for example, this reduces the sample size by 23.)

Energy Use: one plus the ratio of energy consumed to total employment.

Office Equipment: office equipment's share of total capital equipment.

Female Management: percentage of management and owners that is female.

Type of Enterprise: The data set classifies plants by 10 different enterprise types. We omit firms classified as collectives, cooperatives, official entities, and religious communities (overall, these comprise less than $2 \%$ of the sample). We construct dummy variables for Corporations (this includes plants classified as corporations, de facto corporations, and joint stock companies), Proprietorships, and Partnerships (including limited partnerships and joint partnerships).

Industry Tariff: ad-valorem tariff at the 4-digit ISIC level. Provided by Jorge Garcia at the World Bank. The tariff change for a 4-digit industry is simply the difference between 1991 and 1984 ad-valorem tariffs.

Industry Concentration: 4-firm concentration ratio for the 4-digit industry. 


\section{Reference}

Arango, J. and Posada, C. (2005a). Labor Participation in Colombia. Applied Economics, 3\%, 1829-1838.

Arango, J. and Posada, C. (2005b). Labor Participation of Married Women in Columbia. Banco de la Republica de Colombia Working Papers.

Arrow, K. J. (1973). The Theory of Discrimination. In Ashenfelter, O. and Rees, A. (Eds.), Discrimination in Labor Markets. Princeton: Princeton University Press.

Becker, G. S. (1957). The Economics of Discrimination. Chicago: University of Chicago Press.

Becker, G. S. and Murphy, K. M. (1992). The Division of Laobr, Coordination Costs and Knowledge. The Quarterly Journal of Economics, 107(4), 1137-1160.

Berik, G., Rodgers, Y., and Zveglich, J. (2004). International Trade and Gender Wage Discrimination: Evidence from East Asia. Review of Development Economics, 8, $237-254$

Black, S. E. and Brainerd, E. (2004). Importing Equality? The Impact of Globalization on Gender Discrimination. Industrial and Labor Relations Review, 57(4), 540-559.

Black, S. and Strahan, P. (2001). The Division of Spoils: Rent-Sharing and Discrimination in a Regulated Industry. American Economic Review, 91, 814-831.

Brooks, E. (2006). Why don't firms export more? Product quality and Colombian plants. Journal of Development Economics, 80, 160-178.

Carrington, W. J. and Troske, K. R. (1998). Sex Segregation in U.S. Manufacturing. Industrial and Labor Relations Review, 51, 445-464.

Catagay, N. and Berik, G. (1991). Transition to export-led growth in Turkey: Is there a feminization of employment?. Review of Radical Political Economics, 22, 115-134.

Fernandes, A. (2007). Trade policy, trade volumes and plant-level productivity in Colombian manufacturing industries. Journal of International Economics, 71, 52-71.

Goldberg, P. and Pavcnik, N. (2007). The Effects of the Colombia Trade Liberalization on Urban Poverty. In Harrison, A. (Ed.), Globalization and Poverty, pp. 241-290. University of Chicago Press.

Goldberg, P. and Pavcnik, N. (2005). Trade, Wages, and the Political Economy of Trade Protection: Evidence from the Colombian Trade Reforms. Journal of International Economics, 66, 75-105. 
Hazarika, G. and Otero, R. (2004). Foreign Trade and the Gender Earnings Differential in Urban Mexico. Journal of Economic Integration, 19, 357-373.

Hellerstein, J., Neumark, D., and Troske, K. (1999). Wages, Productivity, and Worker Characteristics: Evidence from Plant-Level Production Functions and Wage Equations. Journal of Labor Economics, 17, 409-446.

Hellerstein, J., Neumark, D., and Troske, K. (2002). Market Forces and Sex Discrimination. Journal of Human Resources, 37, 353-380.

Kremer, M. (1993). The O-Ring Theory of Economic Development. The Quarterly Journal of Economics, 108(3), 551-575.

Krugman, P. (1979). Increasing Returns, Monopolistic Competition and International Trade. Journal of International Economics, 9, 469-479.

Melitz, M. (2003). The Impact of Trade on Intra-Industry Reallocations and Aggregate Industry Productivity. Econometrica, 71, 1695-1725.

Menon, N. and van der Meulen Rodgers, Y. (2009). International Trade and the Gender Wage Gap: New Evidence from India's Manufacturing Sector. World Development, 37, 965-981.

Ozler, S. (2000). Export Orientation and Female Share of Employment: Evidence from Turkey. World Development, 28(7), 1239-1248.

Roberts, M. and Tybout, R. (1997). The Decision to Export in Colombia: An Empirical Model of Entry with Sunk Costs. American Economic Review, 87, 545-564.

Roberts, M. J. (1996). Colombia, 1977-85: Producer Turnover, Margins, and Trade Exposure. In Roberts, M. J. and Tybout, J. R. (Eds.), Industrial Evolution in Developing Countries: Micro Patterns of Turnover, Productivity, and Market Structure, pp. 227-259. OUP. 